ARTICLE

Received 19 Aug 2015 | Accepted 9 Nov 2015 | Published 8 Dec 2015

DOI: $10.1057 /$ palcomms.2015.39

OPEN

\title{
Neoliberalism as a political theology of chance: the politics of divination
}

Joshua Ramey ${ }^{1}$

\begin{abstract}
In this essay I argue that despite its increasingly catastrophic social and natural consequences, neoliberalism retains its ideological appeal partly due to the way collective faith in market forces validates neoliberal ideology as a disavowed form of divination. ${ }^{1}$ I begin by briefly canvassing both the history and persistence of divination practices. I then read neoliberal views of random market forces as productive of "knowledge" as a contemporary form of divination practice, defined as any tradition-bound practice of taking chance seriously as a conduit for more-than-human knowledge. I follow Philip Mirowski's argument that under neoliberalism markets are understood primarily as superhuman "meta-information processors" which, partly based on randomness, produce correct "knowledge" about the social good in the form of prices. I argue that the way this chance emergence of "knowledge" is conflated with human freedom, particularly in the writings of Friedrich Hayek, is an uncanny parallel to the divinatory solicitation of chance. Markets themselves are isomorphic with perennial divination tools. Part of the effort to undermine and displace the neoliberal era must involve dismantling the appeal of its particular form of divination, a complex task (not undertaken here) involving exposure of the way neoliberalism offers a simplification of, and authoritarian solution for, complex problems posed by the role of chance in politics, science and metaphysics. This article is published as part of a thematic collection dedicated to radical theologies.
\end{abstract}

${ }^{1}$ Grinnell College, Grinnell, IA, USA 


\section{The persistence of divination}

ivination practices are tradition-bound means of attaining more-than-human knowledge, generally on the basis of a systematic solicitation of chance. ${ }^{2}$ Well-documented by historians, ethnographers and cultural anthropologists, it is a global and perennial aspect of human culture (Curry, 2010: 1). Divination includes practices such as I Ching, Tarot, Ifá, astrology, cheiromancy, bibliomancy, geomancy and sortilege (lots). In addition to these specialized forms, there are many informal modes of divination, states and circumstances in which chance is interpreted as meaningful and oracular. These include oneiromancy (dream interpretation) and hypnagogic modes of awareness such as trance states. Informal modes of divination are often linked to synchronicities, events that seem connected but are not causally related (Jung, 2010). It is thought that the chance words of children and the paranoid speech of the mentally insane can contain divinatory potential, and in many cultures mental illness is taken as a sign of emergent divinatory authority, in need of cultivation and training. ${ }^{3}$ Divination would seem, then, to name some generic, even universal dimension of human culture, a tradition-bound mode of taking chance seriously. ${ }^{4}$

Whether or not human cultures can persist without divination is debatable, since it seems no culture on record has gone without some form of it (Curry, 2010: 1). Yet divination's role is highly contentious. All cultures of divination acknowledge both its salutary and sometimes pernicious potencies. ${ }^{5}$ It is used positively, to resolve disputes, to work healing, for meditational practices and to restore a sense of possibility when situations seem otherwise hopeless. Biblebelieving Christians use bibliomancy, the random opening of scripture, to seek wisdom, even when pastors and priests forbid the practice. ${ }^{6}$ Major firms on Wall Street are known to consult psychics and mediums as part of routine research. ${ }^{7}$ Famous scientists claim to have had their major breakthroughs due to dreams or other seemingly chance happenings in the process of research. ${ }^{8}$ And the State of Arizona still has a legal provision for deciding tied elections by cartomantic divination: in a dead heat, the candidate drawing the higher card wins the race (Heimlich, 2010: 143).

Divination practices can also be pernicious and deceptive. Despite its historical importance and continuing utility for human culture, divination is clearly subject to the wiles of charlatans and the designs of hustlers (Jung, 1967). ${ }^{9}$ From pre-modern authors (Cicero, 2007) to contemporary ethnographers, the evidence is that what makes for trustworthy oracles or valid intuitive insight is subject to doubt, contestation, even the refutation of divination, as such. Cultures of divination have ways to determine whether an oracle was valid, a diviner sincere, a prophet authoritative or not (Taussig, 2003; Cornelius, 2010; Heimlich, 2010).

Even with such mechanisms available, it is clearly difficult to always authenticate an oracle, let alone determine whether a chance is truly meaningful. At least one reason for this is that there seems to be an irreducibly rhetorical or performative dimension involved in divination, some minimal chicane or trickery carried out by diviners, even in the presence of or cooperation with putatively extra-human wisdom (Cornelius, 2010). As an act of interpretation, even though divination elicits higher, non-human authorities, its practice often involves clever persuasiveness, what the Greeks called metis or cunning intelligence, in the taking and interpretations of signs. This presents a conundrum Nietzsche (2001) perhaps put best when he wrote, in The Gay Science \#277:

Nor should we conceive too high an opinion of this dexterity of our wisdom when at times we are excessively surprised by the wonderful harmony created by the playing of our instrument-a harmony that sounds too good for us to dare to give the credit to ourselves. Indeed, now and then someone plays with us-good old chance; now and then chance guides our hand, and the wisest providence could not think up a more beautiful music than that which our foolish hand produces then. (Nietzsche 2001: 157)

Chance can be the occasion for the beautiful music of human wisdom. But is it, as Nietzsche feared, all-too-human? Doubtless the irreducibly inventive dimension of our relation to chance, where we occasionally look for urgently needed wisdom, is deeply fraught, particularly when social and political stakes are high. In a given case, how can we know whether a divination practice protects the status quo of desire and power, panders to narcissistic fantasy, preys upon deep fears, or opens human life to different, unexpected, even life-giving potencies?

Modernity seems to have settled the question of divination largely by avoiding it. ${ }^{10}$ In a putatively secular, rationalistic, scientific context, which claims to have superseded the need for divination, taking divination seriously appears nonsensical, absurd, even a veiled threat to society itself (Lear, 2003). In this anxiety secular modernity is not unique. In both contemporary and premodern monotheistic cultures the affirmation that divination is even possible can lead to charges of heresy and blasphemy-a spurious claim to know the mind of God (Atlan, 2010). This is so even when monotheistic cultures included and still include exceptions for certain kinds of divination (and believers who practice it despite official pronouncements against it).

In the secular rationalist cultures that emerged from the monotheisms, chance tends to be publicly acknowledged only as randomness (Hacking, 1990; Atlan, 2010). That is to say, in modernity chance is supposedly rendered meaningful not through rites of divination but through observation of the properties of complex systems, such as genetic mutation or information processing, that incorporate the aleatory or unpredictable as one of their functional or evolutionary parameters (Atlan, 2010). The meaning of chance is supposed to be apparent only at a level of abstraction afforded by large sets of data to the cool eye of a scientific observer or the indifferent machinations of an algorithm. This sober perspective is in profound tension, however, with the investment of modern subjects in the singular specificity of chance (Hacking, 1990; Lear, 2003). Capitalist subjects are especially invested in gambling, not just for sport but as entrepreneurial risk-taking, where taking one's chances is a form of distinguishing one's life as meaningful, important and auspicious-a sign for others to read, hear, and mark.

Gambling has an archaic connection to divination; most gambling games have their origins in divination rites (Lear, 2003). As Jackson Lear has brilliantly argued, critiques of gambling, in American capitalism in particular, are historically rooted in the anxieties of monotheistic cultures. Modern Protestantism, as Weber already showed in The Protestant Ethic and the Spirit of Capitalism (2009), is particularly unsure about where the power of providence lies in a world that is subject to chance, where economic success is partly a matter of the arbitrary, unforeseeable changes in modes of production and rates of consumption. If a divine design overrules the apparent arbitrariness of chance, how can Christians or other religious believers be motivated to take entrepreneurial risk? Is the entrepreneur playing God? This is not only a religious dilemma. The critique of gambling is also linked to concerns of skeptical rationalists about the disturbance divination might be to reasoned debate as the correct (even if limited) mode of dealing with uncertainty, in both nature and culture (Lear, 2003). How can we govern in advance of chance, or in flexible response to contingencies, without in some sense foreclosing in advance on possibilities that may turn out to have been what was truly desired or needed? The difficulties in coordinating public debate, combined with the urgency of problems that cannot wait for the results of long-term research, often leave the most pressing issues of our time (such as the 
climate crisis) undecided and subject to the caprices of those who happen currently to be in power. They take our chances for us, and divine the meaning of the results.

Perhaps we have never been all that modern(ist), or all that monotheistic. ${ }^{11}$ Perhaps anxiety about divination betrays an uncomfortable truth, that even a putatively modern, secular, and rationalist culture cannot and will not survive without some form of divination. The point is debatable. But what is beyond doubt is that global capitalist culture, particularly in its neoliberal variant, practices its own unique yet disavowed form of divination.

\section{We are all neoliberals now}

The neoliberal era in capitalism, beginning roughly in the late 1970s, has been subjected to a number of insightful analyses and a growing number of wide-ranging critiques. ${ }^{12}$ It is an era defined by the ascendency of financial over industrial and other forms of capital; by increasing indebtedness, public and private; by rapidly growing and extreme wealth inequalities; by de-unionization and extremely precarious workforces; by an increase in the number and rate of financial crises; and perhaps above all by an ideological commitment to the rolling back of the welfare state and privatization of public goods in every sphere, at any price. Despite variations on the theme and disagreements on how best to implement the programme, neoliberalism can be described a general governance strategy designed to re-make homo politicus in the image of homo economicus (Foucault, 2008; Mirowski, 2013; Brown, 2015). The neoliberal mandate, writ large, is to impose markets and market-like processes of production and consumption on more and more of social reality until all of life is included in the ambit of the pursuit of profit. Neoliberalism is arguably the nadir of what Marx called the "real subsumption" of society under the capitalism, a process he saw as possible but did not live to see in its horrifying acualité (Read, 2009).

Neoliberalism is more than a view of economics. It is a total view of reality as conditioned by market forces and human beings as inherently hard-wired for market rationality. Neoliberalism constitutes what Foucault (2008) called a strategy of "governmentality", a way of marking, counting, surveying, and controlling subjectivity in conformity with demands for efficiency, productivity, flexibility and the complete exploitation of so-called "human capital" (Becker, 1994). ${ }^{13}$ At least since the early 1980's, this strategy has been undertaken in the name of human "liberty" as being best preserved in market-based social life (Hayek, 1944; Friedman, 1962). Despite its nearly complete triumph over global political power, it is increasingly clear that neoliberalism does not carry either empirical or historical support for its position that markets are the superior social form and economic activity the best and most desirable expression of human freedom. If this is the case, then neoliberalism is perhaps best understood at this point as a religious doctrine, a faith: in a word a theodicy that endlessly justifies the sacrificial ways of markets to suffering humanity and dying earth (Graeber and Piketty, 2014).

As Mirowski (2013) has shown, neoliberalism has been particularly adroit at hiding its intellectual inconsistencies, and at offering ideological means by which economic hardship and indeed the evisceration of democratic ideals (Brown, 2015) can be sustained by its precarious subjects. In fact the most famous neoliberal voices were explicit about the need for a neoliberal creed to offer a theory not just of the positive benefits of marketbased social life, but of the final appropriateness of marketplaces to fulfil the essence of human nature and form the only true expression of human freedom (Hayek, 1944; Friedman, 1962).

But as Mirowski has argued with extreme lucidity, the neoliberal view of freedom is either reductive or inherently selfcontradictory. In Never Let a Serious Crisis Go to Waste: How
Neoliberalism Survived the Financial Meltdown, Mirowski argues that from its inception in the 1930s at the Mont Pèlerin society, and up to its present day behemoth, the "neoliberal thought collective" has held that the much vaunted "liberty" of classical liberalism must be left undefined or else redefined as a form of knowledge (Mirowski and Piehwe, 2015). While "liberty" is championed by neoliberals as the chief virtue, and in some sense the only one, they either refuse to define liberty other than by opposing it to democratic processes of deliberative action, in the case of Milton Friedman, or with Friedrich Hayek they have translated "liberty" into an epistemic issue. In the latter case, crucial for the argument that markets function as neoliberal divination tools, liberty exists only if and when knowledge as market opportunity is properly realized.

For neoliberals, freedom exists only as the possibility of proper market instantiation and participation. Mirowski's (2013) characterization of the implications of Hayek's view, here, is decisive for my argument.

Freedom cannot be extended from the use of knowledge in society to the use of knowledge about society, because selfexamination concerning why one passively accepts local and incomplete knowledge leads to contemplation of how market signals create some forms of knowledge and squelch others. Meditation upon our limitations leads to inquiry into how markets work, and metareflection on our place in larger orders, something that neoliberals warn is beyond our ken. Knowledge then assumes global institutional dimensions, and this undermines the key doctrine of the market as transcendental superior information processor. (Mirowski 2013: 61)

From the beginning (the 1930s), the view that markets were "superior information processors", where information is supposed to be the genuine facts about what human beings genuinely need and desire, formed the basis for the neoliberal critique of "socialism". This critique was not aimed merely at the totalitarian excesses of communism, nor simply at Keynesian-style attempts to mitigate market inefficiencies through redistributive taxation and other social safety nets.

The critique of socialism by Hayek and then by Friedman was that state formations of rationality-totalitarian or democraticembody a misguided view of reality, itself. Hayek put the point clearly in his mature work on the place of law and government in relation to markets.

It is impossible, not only to replace spontaneous orders by organization and at the same time to utilize as much of the dispersed knowledge of all its members as possible, but also to improve or correct this order by interfering in it by direct commands. Such a combination of spontaneous order and organization it can never be rational to adopt. (Hayek, 1973: 45-46)

Only truly spontaneous orders correctly utilize social "knowledge", and only markets are (or can be and should be) such forms of order. Insofar as the state is not spontaneous but planned, it fails to appreciate both social and natural reality for what it is.

In his writings Hayek was, to his credit, actually trying to argue for this view. And the image of markets as instances of complex, "cyborg" systems of a kind of extended cognition through which the mind is married to a self-adaptive, self-adjusting market, does have some merit (Mirowski, 2002; Connolly, 2013). But the view that markets alone, rather than many other complex systems, embody the model and paradigm of human free creative expression is no longer the subject of argument. ${ }^{14}$ In this way a kind of market "naturalism" (or meta-naturalism) has become a 
retroactive justification simply given, after the fact, for the gutting of the social state, supply-side economics and monetarism that have become the credo of the Washington Consensus, the international finance community, and the wealthiest $1 \%$. More perniciously, faith in the natural and unquestionable character of markets as sociobiological and evolutionary-psychological forces producing and produced by reality itself has become, as Brown (2015) and others have shown in excruciating detail, the very air that the other $99 \%$ of capitalist subjects (cannot) breathe. Neoliberal ideology is now the deep framework within which every decision is made-from career choice and political persuasion to health and education to love and relationships. Neoliberal subjectivities frame every scenario as an investment opportunity realized or lost, on the model of evolutionary-adaptive success or failure within a chaotic, hostile, hypercompetitive scenario of scarce resources.

As Foucault was perhaps the first to see clearly, Hayek, Friedman, Becker and their acolytes were adamant that this most "natural" way of humans to be-not homo politicus but homo economicus, investors of human capital-needed to be enculturated. That is, subjects and societies had to be instructed in the ways of the market, disciplined by and reshaped for markets and market-like modes of interaction. History has shown this is a process that meets with continuous resistance. Yet here is one of the contradictions that can be exposed in the neoliberal synthesis. As Mirowski (2013), Crouch (2011) and Peck (2010) have all documented, it is only the neoliberal inner circle who ever need know, as a reasoned philosophical position, that the only path to freedom and dignity is through markets. It is imperative for most of us to merely believe. As Hayek (1944) put it:

Probably it is true enough that the great majority are rarely capable of thinking independently, that on most questions they accept views that they find ready-made, and that they will be equally content if born or coaxed into one set of beliefs or another. In any society freedom of thought will probably be of direct significance only for a small minority. (Hayek 1944: 164)

For the insiders, there is understanding. For the rest of us, there is sacrificial participation. In fact, as Mirowski put it above, if enough of us developed an awareness of our very real limitsecological and psychological-and the limitation on market logic to capture the complexities of other aspects of life, we might lose our nerve and our faith. So "market fundamentalism", as George Soros famously dubbed it, is imposed in order to prove that it is true. It is imperative that we do not ask why the only solution to apparent market failure is to continue the project of further market refinement and implementation, or the project will collapse in on itself.

\section{Disavowed divination}

Maintaining the ignorance of the masses as to real market forces, as neoliberalism insists must be maintained for markets to work properly, produces a state of greater and greater social and natural chaos, the equivalent of a continuously and globally unfolding "state of emergency". Thus the "politics of divination" practiced by neoliberalism is a variant on the authoritarian political theology of Schmitt (2006). In states of emergency such as terrorist attacks or financial panics, as Schmitt argued, democratic processes will always be too slow, and in need of a speedy authoritarian supplement. There must be "exceptions" made for leaders of superior insight and wisdom to overrule and override democratic processes, such as when George W. Bush declared, "I am the decider". Schmitt (2006) had argued precisely for the need for something like the rise of an authoritarian state (such as the Nazi party) in the face of the economic chaos of the collapse of the
Weimar republic. The trick of neoliberalism has been to produce a state of continuous economic emergency in which the only way out is through: only the authority of the as-yet-unrealized market can save us from market deficiencies with respect to the social good, since the true social good can only be known through full surrender to market meta-information processing. Thus the politics of divination as neoliberal political theology: the only meaning of chance to be divined is that which enforces the authority of the ideal, never-quite-realized market. The truth of that market, its true shape, is known only to the initiates. To be consistent, even the "exceptions", our neoliberal sages, must claim as Friedman (1962) did, to be just like us, just trying to know the unknowable. Just trying to practice divination.

Given the catastrophic social and natural consequences of this ideology, individuals and institutions can only remain convinced if they believe markets are a certain kind of ideal that has not yet been, but can and must be realized on earth. From my perspective this is one of the core contradictions (there are others) in the neoliberal era that demands ideological suture, and thus offers a certain amount of critical leverage. We can believe in neoliberal ideology, and perversely do enjoy it, partly out of how neoliberalism draws upon a limited and disavowed form of divination to satisfy contemporary demands for rendering chance meaningful. It thus plays upon confused (and confusing) conceptions of risk, uncertainty and randomness - in a word, conceptions of chance-that plague the modern mind. Drawing upon ambiguities in secular, modernist and scientific concepts of chance, neoliberal sages disavow the divination they perform. This disavowal is possible on the basis of the putatively anonymous and supra-human forces markets are supposed by neoliberals to embody.

Let me begin to substantiate this claim. There is a particular role for chance, at least as randomness, in markets. Hayek reserves his highest praise for the spontaneous and unforeseeable emergence of market "order".

It was men's submission to the impersonal forces of the market that in the past has made possible the growth of civilization... It does not matter whether men in the past did submit from beliefs which some now regard as superstitious... The refusal to yield to forces which we neither understand nor can recognize as the conscious decisions of an intelligent being is the product of an incomplete and therefore erroneous rationalism. It is incomplete because it fails to comprehend that co-ordination of the multifarious individual efforts in a complex society must take account of facts no individual can completely survey. And it fails to see that... the only alternative to submission to the impersonal and seemingly irrational forces of the market is submission to an equally uncontrollable and therefore arbitrary power of other men. (Hayek, 1944: 204-205)

Thus Hayek's famous claim that true social order depends on ignorance, not on rational planning. Hayek here holds complexity and unforeseeable coordination as the keys to growth, invoking a quasi-ecological and systems-theoretical notion of order emergent from and within chaos. This is precisely a claim for the natural, inevitable and yet unforeseeable role of chance in the development of life itself. The claim, by itself, is relatively uncontroversial (Connolly, 2013). But markets, for Hayek are held to be the only social form that properly accounts for the chance or randomness that is by nature a part of the spontaneous development of order within complex-that is to say partly chaotic-systems. State planning fails because it is a naïve, insufficiently sophisticated relation to nature.

How exactly is this naturalism about markets cashed out? Markets, if they are close enough to equilibrium, are supposed to respond to contingent shifts in supply and demand as much as 
they also elicit and produce such shifts. Thus chance is at the heart of both marketplace behaviour and analysis. Chance here is not, of course, complete uncertainty. Chance must be restrained-it must be calculable risk, not genuine uncertainty, as the neoliberal Knight (2009) argued far in advance of the triumph of neoliberal order. ${ }^{15}$ Systems of probabilistic logic embodied in algorithms that enable the survey of vast tracts of data may assist in the anticipation of possible events, in both social and natural worlds, but are only useful if the future remains in relative continuity with the past (Amoore, 2013). In terms of markets and capitalism, this means that unforeseen contingencies are "significant" (that is, profitable to someone) only if they do not entirely disrupt previously comprehended tastes, desires, drives, and demands-that is, only if contingencies are not radical enough to jeopardize markets, as such.

Put differently, chance changes are only meaningful as profitable, only, that is, if they lie within a continuum of manageable risk, not as real uncertainties (including the uncertain status of markets as such, dependent as they ultimately are on social and political will and perhaps most importantly on ecological stability). In order to achieve maximum profitability, it is imperative that neoliberal capital produce the future in the image of a past that has been itself reproduced: the next installment of market forces must be what we will have wanted, but were not quite getting, all along.

Hence the importance of reading neoliberalism as a form of divination, since divinatory wisdom is generically that which we rely on in order to attune ourselves appropriately to a present partly determined by forces otherwise unknown in the past and unforeseeable in the future. With the deliberate introduction of chance in divination rites (and its echo in neoliberal market idealism) comes a paradoxical re-interpretation of the past and anticipation of the future as contingent, as not what it seems (or more than it seems) to be.

There is thus a divinatory attitude to markets in neoliberalism. Divination, by seeking hidden or unknown causes, is a kind of dis-entangling of the present from its apparently foreclosed nature or as a foregone conclusion. In traditional divination, the material production of chance (as random cast, spread or synchronistic observation) in some sense mimics or rhymes present uncertainty with cosmic contingency, and creates the opportunity to justify or explain the present rather than merely to accept it. Here lies the neoliberal card trick. For it is by foreclosing all other interpretations of an undesirable present other than having been produced by a past in which "markets were not yet fully operational" that neoliberal divination manages to convince us to keep attempting to re-make the future in the image of a past that never was-a past when there might have been and should have been perfectly operative market forces. There is only one oracle, one message and one chance: for the further and more perfect extension of market forces into more of human reality, rendering it finally subject to the only conceivably meaningful chance we will have had: to render ourselves profitable, or die.

In the early twentieth century, Weber (2009) already argued that a version of secular providentialism was the necessary ideological supplement to the terrors and tribulations of market uncertainty, as early as the seventeenth century. But in the neoliberal era, as Kotsko (2015) has recently observed, it seems we have devolved, and minimized our ambitions for a meaningful life. That is, we have abandoned any reference to a providence in any sense external to markets, opting instead for a more immanent and sinister economic theology in which the ultimate purpose of market forces is simply to reproduce market forces, on the model of the inevitable sorting of random traits in a socio-biological quest for an "equilibrium" within competitive adaptive mutation.

In order to justify what is and is not available, produced, included and/or excluded from the market, let alone to justify inequalities of wealth and power, the process as a whole must be made to appear spontaneous and yet driven by inexorable evolutionary forces. To square this circle, and to marry meaningful chance exclusively to the ideal husband of market order, there must be, under neoliberalism, some kind of interpretive practice that continuously reassures market-bound subjects that their arbitrarily cultural fates are in fact perfectly natural and inevitable. That practice is a form of divination. Neoliberal divination is the obscure, disavowed public face-anonymous, implacable, inscrutable-of an authoritarian scheme to restrict chance to fate: to use a heady brew of chaos and market (dis) order to protect the largest and most powerful interests of capital at any cost (Klein, 2008).

\section{The stars down to earth}

How to reconcile chaos and order is not a new human problem. The gap between meaningless randomness and meaningful chance must always, in some sense, be ideologically sutured. That such suture has traditionally been the provenance of priests and oracles implies that neoliberalism, if ideologically successful, is both a political theology and a theologized economics. That is to say, neoliberal market fundamentalism is perhaps only a new twist on how to satisfy an old, pre-capitalist need for meaning.

Theodor Adorno's insight, in an essay written at the height of Fordist capital, was that continuing devotion to astrology by capitalist subjects in the 1950s (before the ascent of neoliberalism) reflected a need for authoritarian reassurances in the face of unjust, inequitable fates. For Adorno, an "irrationalist authoritarianism", itself a symptom of the impossible quest for domination of nature by "enlightened" human culture (Horkheimer and Adorno, 2007), is reflected in continuing devotion to astrology by otherwise good rationalistic, sober minded utility maximizers confronting economic scarcities and legal constraints. In "The Stars Down to Earth", Adorno (2001) argued that continuing attachment to procedures of divinatory reading, such as astrology, are displaced accounts of our dominance by the demands of capital, a projection onto cosmic inscrutable forces (the planets) of the contingent, ruthless, exploitative development of capital on earth. But in this Fordist phase of divination, we seemed to be recognizing, effectively, that there really never was a chance, that no one really ever had a chance Outside of her allotted institutional and administratively rational role. How then, under neoliberalism can we seem to divine genuine chance in markets?

The shift has to do in part with the expansion of the working day and the working world into every area of human life, each human capacity, every moment of subjective time. With the rise of the "cognitive" or "affective" or "sharing" economies, all human energy becomes a potentially profitable resource to exploit (Mirowski, 2013; Brown, 2015). To extend the point beyond what Adorno could perceive, with neoliberal divination we are no longer pulling the stars down to earth, making gods out of our bosses, but also in the perpetual, infernal process of becoming stars ourselves, burning up our resources at ever greater speeds and intensities. This calls for the more intimate, distributed, and seemingly anonymous and impersonal power of markets to divine ever more of our chances. Anxiety over unfolding contingency seems to be no longer assuaged through a divinatory invocation of sacred or higher wisdom. For neoliberal subjects, there is no other wisdom other than the unfolding transcript of why a contingency, a chance, was or was not yet captured by someone as profit. And the only oracles left are those who seem to know how markets really work (even though such knowledge is supposed to be impossible).

This brings us to the heart of the neoliberal chicane. As Klein (2008) and others have observed, it is not only in the interest of neoliberals to restrict the meaning of contingency to profitability, but also to systematically provoke certain kinds of disorder. 
This extends even to taking over and remaking governments from Chile to Iraq in order to service the largest capitalist interests need for growth: the prison-military-industrial complex, global finance and the high technology industries, in particular (Perkins, 2005; Klein, 2008). Thus neoliberalism seems to have it both ways: to both restrict the meaning of chance in advance, and to reproduce randomness, risk and disorder that is susceptible only of market "solutions". In either case, in the neoliberal era, rather than promising future happiness outside the working day, occult knowledge of the "mind of markets" is used to retroactively justify the suffering of the present as inevitable, as our only individual and collective hope in the face of failed (or simply presumably failed) alternatives to markets. ${ }^{16}$

What I mean by neoliberal divination, and by neoliberalism as a political theology of chance, is not that markets are used to predict the future or foretell destinies. Perhaps unlike Fordist divination (Adorno, 2001), neoliberal divination is not a form of soothsaying. More mundanely put, any relatively sober economist or financial planner admits that future risk-the likelihood of success or failure of an investment-can only be assessed in the extremely near term and within extremely stable political, ecological and economic variables. In fact the entire point of entrusting ourselves to markets, according to Hayek, is that the future cannot be predicted, let alone controlled. We need the God of the Market to whom to entrust our fates.

Thus when I call neoliberal market apologetics a divinatory justification, I am not especially drawing attention to the movements of markets as an anticipation of the future, even though within very tight limits there is some warrant for this. Neoliberalism is better understood, rather, as an attempt to foreclose the future in advance, in part by foreclosing on the meaning of chance (restricting it to potentially profitable risk) and in part by producing or allowing catastrophic situations, states of emergency that only the alreadylargest firms and interests can "manage" ${ }^{17}$ By calling neoliberalism a politics of divination I mean to capture the sense in which retroactive stories about market success or failure, market efficiency or inefficiency, are isomorphic with traditional uses of divination to understand the meaning of how events have unfolded into a given present, and why. The irony of the fact that neoliberalism is supposed to be a philosophy of freedom, and yet whose free market fundamentalism has produced the juggernaut of the state-financemilitary-surveillance-prison-industrial-technology complex, surely cannot be a point lost on anyone for much longer.

\section{Neoliberal political theology: a theodicy of chance}

Neoliberal ideology, instantiated as a divinatory process of interpretation, reads events in terms of their relation to and transcription of chance insofar as chance reveals only what markets should have been. This kind of divination has become the unquestioned framework within which all questions of meaning, purpose and order can be posed: how to extend markets and to make them run more efficiently as total social systems of determination. Neoliberalism generalizes our intimate, everyday familiarity with uncertainty, and our need for everyday forms of divination, in order to provide a kind of monotonous theodicy of chance. Thus what is divinatory about markets under neoliberalism is the way they both satisfy and betray our more general hunger for divination. The entire world, the universe itself, is figured as a market, and chance in nature is both framed as and subordinated to those actionable risks that might make someone profit.

This naturalization of market "forces" justifies the suffering, exploitation, and ecocide involved in the endless market demands for efficiency, predictability and control-in a word, for profit. If divination is traditionally used primarily to comprehend why events have unfolded the way they have, for individuals or groups, on the basis of its ability to reveal hidden forces at work (Tedlock, 2010: 19-23), then under neoliberalism (as far as it holds sway) we have come to accept that market forces are the one and only intelligible divining rod. This is so by a kind of pseudo-scientific authoritarianism (as Adorno recognized), but also by the felt and arguably irreducible need in human culture for public rites of divination, what Adorno's friend and colleague Walter Benjamin understood as the ironic prophetic potential of the gambler, appearing in late capitalism as a simulacra of the authentic prophet (Downing, 2011).

In lieu of such prophets, the intrepid entrepreneur, the entrepreneurial self we are all now more or less constrained to be, is the obscure and hypnotic figure who is now worshipped as the immanent god, the genie of evolutionary creative destruction. This ersatz combination of the prophetic and the authoritarian, the gambler and the rational planner, is the ideal (and interpolated) reference point, the (never quite realized) image of total success that frames every neoliberal evaluation of a life, an event, a chance. What I call the "politics of divination" names the archaic prestige that lends this figure its profound, even sacred glamour despite the unjust, inequitable and ecologically catastrophic consequences of our continuous consultations with that particular oracle of supposedly higher wisdom, the Market.

\section{Politics of divination}

This argument needs to be made slowly and carefully if it is to help us appreciate and alter the absurd form of public religion we currently practice, in consultation with our neoliberal oracles. At the heart of divination is the practice of relating to chance as an occasion to make meaning-to read, interpret, imagine and act in ways otherwise impossible. Under capitalism we practice divination primarily through participating in markets. It is here that most of us take our chances (where we officially, as opposed to privately gamble). Our economic fates are the public meaning ascribed to our lives. And yet contemporary secular, scientific cultures that interpret chance as randomness putatively deny meaning to chance (Atlan, 2010). What this means is that insofar as it pretends to scientificity, neoliberal divination can be disavowed through an equivocation about the meaning of chance.

On the one hand, chance as historically understood is always meaningful in relation to individual or collective purposes. But insofar as what occurs is an expression of random forces not subject to individual control, what happens is ultimately without why, and meaningless. But this is not a problem neoliberalism invented, and perhaps neoliberalism exists, at all, as a symptom of the fact that modern democratic politics, scientific discourse and metaphysical thinking all waver between two incompatible senses of chance as either singular and meaningful or meaningless and arbitrary (Hacking, 1990; Atlan, 2010). Neoliberal equivocation about chance (expressed primarily in the work of its master thinker Hayek, but also in its more popular voice Milton Friedman) is a very deep one, linked to and dependent upon broader political, scientific and metaphysical confusions about the role and nature of chance.

Thus the claim that we need to interrogate the politics of divination and its role in the contemporary world is not simply an invitation to critique the intellectual core of neoliberalism, but also to examine, at the level of lived experience, the contradictory way in which neoliberalism's mutating policy positions and institutional experiments and popular media stump-thumping play out across larger ambivalences about the role of chance in modern life.

Within neoliberal ideological and institutional frameworks, a form of reading chance- - a form of divination-is exemplified in the risk management techniques of market participants, where uncertainty is read as opportunity for potential profitability. And under neoliberal hegemony, market values of efficiency, productivity, flexibility and 
profitability are iterated elsewhere, dominating not only in economic life but in general strategies of governance-of surveillance and control-at both macro- and micro-levels of power. Under neoliberalism, market forces and market-modeled interactions are increasingly used as the norm for understanding all other complex systems (including the so-called "economy" of terrestrial life itself). ${ }^{18}$ Thus neoliberalism is an ideology that "reads chance aloud" (Heimlich, 2010) by translating all questions into queries about what can be turned to a profit. That is to say, in the neoliberal culture of risk management, the logic of markets is employed to observe, predict and control bodies, societies and even the earth itself on the model of efficient profit-seeking.

This makes markets de facto divination tools far beyond strictly speaking "economic" activity, since market outcomes-random processes of assortment and allotment based on aggregates of supply and demand-are thought to reveal, beyond any particular will, the only truly universal and perfectly generic oracle of what will have been meaningful, worthwhile, and even the truth of human freedom. Under neoliberal hegemony, this is so not because certain individuals or institutions explicitly identify with their economic success or failure, but because all individuals and institutions (and indeed earth itself) are forced by market fundamentalism to do so, in the last instance. As the ideal social transcription of natural forces, "economic values" frame and over-code all discussions of policy, procedure and even of law itself (Becker, 1994).

Insofar as a general market-modeled strategy of neoliberal governmentality develops across all control systems, a disavowed form of divination is practiced. Neoliberal divination is practiced as a disingenuous reading of chance, a covert reduction of chance to manageable risk masking as genuine opportunity for the making and unmaking of meaning. As a general and internalized governance strategy based on the model of marketplace behavioural norms, neoliberalism does not elicit the potential meanings of chance, but attempts to foreclose on the uncertain in order to restrict all chance to potentially profitable risks.

Unlike my modernist predecessors Adorno and Benjamin, I do not believe there is a way out based in skepticism about the validity of divination itself. I not arguing that markets are not divination tools, or that they should not be, or that market interactions cannot count as divinatory. Rather I am claiming that neoliberal divination is too narrow, too coarse, and too easily disavowed. It is a politics of divination that enables our ersatz sages to mask the discernment of destiny in chance behind pseudo-scientific jargons of blind mechanical forces of randomness. Obviating the fact that in marketplace interactions individual human destinies are truly at stake, and the related fact that our destinies (in markets and without them) have always been divined partly on the basis of a creative, interpretive relation to chance (Nietzsche, 2001), neoliberalism exonerates markets as the only truly appropriate arena of human communication and creativity, foreclosing the meaning of chance, in advance, reducing it to potentially profitable risk. In consequence neoliberalism all but eliminates contesting interpretations of the value, promise, or threat of chance, since chance figured as profitable risk allows it to answer one and only one question: will event $x$ have been profitable?

\section{Sacrifice and surrender}

The irony, however, for a modern, secular, post-scientific culture such as late capitalism claims to be, is this. Given the apparently irreducible role for some kind of divination in human culture, it is in part because markets are structured as divination tools that neoliberalism succeeds. All cultures of divination practice some form of discernment, and even contestation, about whether and how to use oracular relations to chance. But neoliberalism's disavowed form of divination undercuts whatever processes of contestation-in particular those of liberal democracy (Brown, 2015) that might enable anticipation and even production of future contingencies in accord with values other than those of profit, efficiency and the endless quest for control over chaotic systems.

In short, my argument is that markets enable only an extremely limited and truncated form of divining chance, and one that can thereby be disavowed. As disavowed, neoliberal divination is not subject to contestation or protest. That is, neoliberalism offers a seemingly satisfying and putatively global form of divination: total social coordination in relation to chance as profitable risk. But the appeal of this divinatory attitude toward markets, in view of the sacrifices it demands must draw on archaic attitudes to chance as sacred. More generically, it draws on the felt need to lend unfolding contingencies some form of public or at least shared interpretive strategies.

Divination rites are often linked to cults of sacrifice. Perhaps most importantly it is this sacrificial aspect of divination that neoliberalism can hide (even though it is glaringly obvious) behind gestures toward socio-biological, cybernetic and informationsystems models of market "reality". Translating the oracular power of chance into the pseudo-science of risk management (Amoore, 2013) undermines the imputation of any truly oracular, prophetic, even merely meaningful quality to the marketplace forces neoliberalism nevertheless praises as the essential embodiment of human freedom. If market "realism" claims they are blind, mechanical systems of order emerging in randomness rather than as service to any particular gods, then the sacrifices made to those gods-even the sacrifice of planet earth itself-can be disavowed.

It might seem a stretch to claim that any neoliberal thinker would explicitly make such a claim, let alone that such a claim would be embodied as divination in institutions and practices or form part of an individual's explicit worldview. Yet the ideas of the most important and popular voices of neoliberalism, from Hayek to Becker to Friedman, all converge on precisely the paradox that the meaning of freedom is to surrender one's will to market forces. For society to know itself as what it truly is, is for social life to be governed not by the wisdom of rational planning but the chaotic emergence of order from the clash of evolving forces in markets. Economic life must be shown to involve massive inequities and huge amounts of waste and destruction just as earth is home to so many hurricanes, volcanoes and meteorite impacts. Climate change from this point of view might be the most natural thing imaginable, and can certainly be turned by someone to a profit, probably whoever has proprietary rights to climate-cooling technologies (Mirowski, 2013).

Even if many neoliberals are beginning to lose their nerve in the face of the climate change catastrophe, political instability, and social upheaval caused by the continuing failure of the global market-state, there is a deeply archaic political problem neoliberal ideology seems to solve, a problem that arguably will not disappear with neoliberalism. That is the perennial human problem of how to relate to chance as meaningful. The apparent solution to this problem, the reduction of chance to mere "noise" in the metainformation processor of markets, gives neoliberalism part of its continuing, if ever-more diffuse and obscure appeal. The problem of how to practice divination remains unresolved in modernity as a global, secular, rationalist project, but the apparently scientific (if disingenuous) divinations of market forces has made neoliberal ideology so appealing that it continues to linger and loom large despite its obviously destructive consequences.

\section{Notes}

1 The essay supports the argument of my forthcoming book, Politics of Divination: Neoliberal Endgame and the Religion of Contingency (Rowman and Littlefield, Intl., 2016) 
2 For a summary of several current scholarly definitions of divination, all of which converge on and are consonant with my admittedly laconic formula, see Allison et al. (2010: 252-253).

3 Recognition of mental illness as potentially divinatory or a sign of someone with potentially oracular gifts is particularly prevalent in cultures that still recognize the role of shamans as healers and authorities in disputes (Petikäinen, 2010: 53).

4 Readers hoping for a socio-biological or evolutionary-psychological account of the role of divination in the development of the peculiarly human animal will be disappointed by what follows. While this perspective would raise fascinating questionsdo animals practice divination? If not, why does the human animal, and what role does such activity play in relation to evolutionary drives to survival and adaptation?they would take me beyond my ambit here.

5 In his classic study, Evans-Pritchard (1951) was adamant that the Azande maintained a healthy skepticism about the powers of their witch doctors to perform both healing and divination. In more recent scholarship, Geoffrey Cornelius, in a study of witch doctors not only in Africa but world-wide, brilliantly demonstrates just how complex the relationship between client and diviner can be (2010). He argues that divination among the witch doctors involves extremely nuanced elements of performance or trickery (chicane) by which the client may or may not be persuaded, and thus healing and/or insight may or may not be affected. In a study of both monotheistic (Jewish) and scientific (post-Darwinist) anxieties about continuing human reliance on divination, Heimlich (2010: 175) argues that modern insistence upon the absence of warrant for divination can only be disingenuous: "one marks the absence of inscrutable cosmic pattern only because human beings 'always already' have honored cosmic pattern, but one officially can no longer honor such blasphemy."

6 Intense ambivalence among Christians over this practice, which led St. Augustine to his conversion but is officially forbidden by scripture itself (Augustine, 1961), can be seen in the richly contradictory instructions for modern Bible users found on the internet (gotquestions.org, accessed October 2015)

7 For documentation of the history of consultation by major business and political leaders, see Supernatural America: A Cultural History (Samuel, 2011). For recent reports of wealthy and powerful executives and financiers who regularly consult with readers, intuitives, mediums, and other diviners, see Marinova's (2015) report of the popularity of Colette Baron-Reid, the so-called "psychic of wall street." In the same article Marinova reports that at last count the 1.9 billion dollar psychic services industry grew $2.2 \%$ from 2009 to 2014 .

8 Although this would be a highly controversial claim, it is arguable that science practices something like divination at the level of what C.S. Peirce (Hartshorne and Weiss, 1934: 172) called abduction: the intuitive guess at the best possible explanation of a phenomenon, forming a proposition that can then be tested by induction. Observing wet ground, one may leap to the initial hypothesis that it rained last night, even though no inductive sampling of the causes of wet ground render the proposition more likely than any other. It is by chance that one selects one hypothesis over another. Yet Peirce insisted that our confidence in science reveals that we presume some basis for why, over time, abductions tend to converge on propositions more and more likely to be true. It would be a much longer and more complex argument to draw out parallels and differences between abduction and divination. But the work of Peirce-inspired philosophers like Zalamea (2012), Nagarestani (2014) and Gangle (2015) all suggest that diagrammatic reasoning, reasoning in and through diagrams, does not merely represent but in some sense can produce new knowledge, rendering the otherwise invisible visible. Scientists and mathematicians who use diagrams in this way could also be said to be practicing-controversially, I admit-a certain form of divination. Here the oracle might be said to be "nature itself," at least on a realist view of science. Gangle has also interpreted divination practices used over time for contemplation as being susceptible to a rationalist interpretation as a form of diagrammatic reasoning (Gangle, 2010).

9 See especially Glucklich's The End of Magic (1997), a study of both devotion to and ambivalence about the divinatory deliverances offered by hundreds of oracles to clients at Banaras, one of the most important centres of contemporary occult practice in India.

10 This avoidance of divination is linked, I will argue, to the project Hacking (1990) famously called The Taming of Chance. The avoidance of critical or rational discourse on divination in modernity reflects a fundamental ambivalence about chance in modern scientific cultures. As Hacking puts it, on the one hand chance is seen as tamed by the calculus of probabilities, and so allowed a role in scientific discourses theorizing predictable natural phenomena. On the other hand, modern poets, musicians, and philosophers have tended to insist on a wilder sense of chance as an unaccountable singularity that has unforeseeable, unlawful effects. I will argue that neoliberalism's praise of the "creative destruction" wielded by market forces is compelling for how it makes economic activity a cipher of both senses of chance, providing a false sense of unity and coherence (that is, an ideology) through its faith in markets as, contradictorily, random forms of order.

11 Here I am obviously riffing on the work of Bruno Latour $(1993,2010)$ here, who has long argued against the value of any critical theory in which the "modern" or "enlightened" or "secular" can in any meaningful sense be distinguished by opposition to the so-called "primitive" or pre-modern mind. For Latour any socially or politically critical project (such as critiques of capitalism) beginning with a "disenchantment of nature" is doomed. This is, for Latour, because epistemically, pragmatically, and ultimately ontologically there is no clear sphere of "culture" to be distinguished from "nature," as evidenced by the essential mediating functions between nature and culture played by scientific instruments, disciplines, traditions, and conceptual models in the development of the "truth" about a nature supposedly external to that very scientific culture. Divination practices are archaic modes of mediating the natural and the cultural by way of an interface between the unforseeability and unknowability of chance and the prior expectations and future hopes of a community. It claims, from a Western point of view, to violate the divide between matter and mind, world and representation. It can thus appear to be a primitive or atavistic trace of the pre-modern in the modern. And indeed the persistence of divination argues that we have never been modern. The work of Eduardo Viveiros de Castro argues stridently that Western philosophical oppositions of mind and matter, nature and culture, cannot begin to capture the complex "polynaturalism" of nonmodern peoples (Viveiros de Castro, 2004: 484). De Castro’s work, along with Latour and other anthropologists like Taussig (2003), support my contention that a critique of neoliberal divination cannot begin by "debunking" divination as superstition or irrational, but rather should be approached as a set of practices (rather than beliefs) that both manifest and create an ontology, worlds that like all worlds are as real as they continue to be enacted.

12 The most important of these, for my purposes, are those of Foucault (2008), Harvey (2007), Mirowski (2013), Crouch (2011), Peck (2010), Read (2009) and Brown (2015).

13 Brown's (2015) otherwise excellent account of the demise of liberal democracy at the hands of neoliberalism has been justly criticized by Dean (2015) as being insufficiently attentive to the way in which neoliberalism is not a monological, systematic, or even in the last instance coherently rational political strategy. It is better understood, I agree with Dean, as an ideology in what she calls the "broadly materialist sense" advocated by Slavoj Zizek (Dean, 2015). When neoliberalism is approached as an ideology, the focus shifts from whether it is reasonable to adopt this position to why subjects remain invested in it. And as Mirowski (2013: 69) has shown in great detail, the genius of neoliberalism, historically, is to maintain simultaneous levels of coherence and incoherence (what he calls "double-truth doctrine") in order to maintain capitalism as an experimental site of social engineering masking as nonengineered free creative human expression. The question, from my perspective, as well as Dean's and Zizek's, is why capitalist subjectivity continues to perversely enjoy the particular form of suffering this experimentation entails. What desires does it satisfy? At least one of those desires-neither rational nor irrational, on my nonmodernist approach-is a demand for genuine divinatory practice. There is a rhetoric of destiny, fate, and even simply of meaning offered by neoliberalism that sutures or sustains a series of contradictory but compelling views of contingency emitted from modern political, scientific, and philosophical research. These contradictions centre on difficulties in living with chance. It is thus, on my account, both intellectually and spiritually satisfying as an account of the necessity of destruction as a form of sacrificial propitiation of the chaotic forces recognized by secular political theory, scientific discourse, and non-theistic metaphysics. That is my larger thesis, at any rate.For the record, Dean's critique takes nothing away from Brown's indispensible analyses of, among other pernicious effects, how liberal democratic ideals of popular sovereignty have been replaced by models of corporate governance and managerial strategies, where goals and outcomes (that is, profitability) are presumed desirable in advance, and politics is reduced to competing conceptions of efficiency and even of "creativity." Brown's analysis is simply limited to accusing neoliberal subjects of "civilizational despair" without treating that despair as either psychoanalytically symptomatic, as Dean does, or as religiously persuasive, as I do here.

14 Connolly (2013) has argued persuasively that social movements, artistic styles, and scientific research breakthroughs, among many other social forms of emergent knowledge, can be shown to be just as much if not more the adaptive, spontaneous, auto-poetic forms of order that Hayek imputes supremely to markets.

15 Despite drawing very different policy conclusions than neoliberals, Taleb (2010) also avers that markets can only handle limited forms of short term uncertainty and cannot anticipate "black swans" or completely unforeseen contingency. For a different view of contingency in relation to markets see Ayache (2010). Ayache holds that, at least in the case of markets in options, futures, and derivatives, markets not only can account for the unforeseeable, but that the ability of traders to "write" options prices is literally the creation of unforeseeable contingencies, as such. Ayache's argument is that if options prices were in any real sense foreseeable, or even rational (that is, based on movements of the underlying assets upon which options hedge), then the options market would be "redundant" and collapse, reflecting only the movement of underlying assets. There would be no incentive to trade futures if different futures could not be created by traders, and traders can only create new futures in the market by affecting (in the rhetorical, performative sense) the attraction of certain prices, which can be done, Ayache claims, only by staying in the market, or maintaining its speed and intensity. I agree with Steven Shaviro that this accelerationist fantasy (Shaviro, 2015) leaves much to be desired both as a metaphysical view of contingency and as a starting point for political economy.

16 It is striking that this retroactive role for divinatory knowledge is not only much more similar to Benjamin's well-documented (Downing, 2011) preservation of divination as a reading practice (much to Adorno's chagrin, who preferred negative dialectics), but is also closer to the way that divination is, on balance, globally undertaken. The ethnographic evidence clearly shows that even from a merely quantitative perspective, divination is more often a retrospective than a prospective enterprise (even 
though it is also used to attempt to forecast the future). This gives us a different way to critique neoliberal subjectivity as implicated in a disavowed practice of divination.

17 And in the last instance, this looks increasingly, even to those like myself who are not conspiracy theorists, as if the only candidate left to manage catastrophic global climate change and social unrest is a para-state behemoth of world governance, the global military-prison-financial-industrial-state-surveillance complex.

18 This is ironic because as Mirowski (2002) and other show, economics borrows extensively from the natural sciences and mathematics.

\section{References}

Adorno T (2001) The Stars Down to Earth. Routledge: London.

Allison C, Stapp P, Thorley A, Wadsworth J (2010) Clarifying divinatory dialogue: A proposal for a distinction between practitioner divination and essential divination In: Curry P (ed) Divination: Perspectives for a New Millennium. Ashgate Publishing Limited: Farnham, UK.

Amoore L (2013) The Politics of Possibility: Risk and Security Beyond Probability. Duke University Press: Durham, NC.

Atlan H (2010) The Sparks of Randomness, Vol. 1: Spermatic Knowledge. Stanford University Press: Stanford.

Augustine. (1961) Confessions; trans. R.S. Pine-Coffin Penguin: New York Ayache E (2010) The Blank Swan: The End of Probability. Wiley: New York.

Becker G (1994) Human Capital: A Theoretical and Empirical Analysis with Special Reference to Education, 3rd edition, University of Chicago Press: Chicago.

Brown W (2015) Undoing the Demos: Neoliberalism's Stealth Revolution. Zone Books: Cambridge, MA.

Cicero. (2007) On Divination, Volume 1. Oxford University Press: Oxford.

Connolly W (2013) The Fragility of Things: Self-Organizing Processes, Neoliberal Fantasies, and Democratic Activism. Duke University Press: Durham, NC.

Cornelius G (2010) Chicane: Double-thinking and divination among the witchdoctors In: Curry P (ed) Divination: Perspectives for a New Millennium. Ashgate Publishing Limited: Farnham, UK.

Crouch C (2011) The Strange Non-Death of Neoliberalism. Polity: Cambridge, UK.

Curry P (2010) Introduction In: Curry P (ed) Divination: Perspectives for a New Millennium. Ashgate Publishing Limited: Farnham, UK.

Dean J (2015) “Neoliberalism's Defeat of Democracy”, Critical Inquiry. Available from: http://criticalinquiry.uchicago.edu/neoliberalisms_defeat_of_democracy, accessed 30 October 2015

Downing E (2011) Divining Benjamin: Reading fate, graphology, gambling. MLN; 126 (3): 561-580.

Evans-Pritchard E E (1951) Witchcraft, Oracles, and Magic Among the Azande. Oxford University Press: Oxford.

Friedman M (1962) Capitalism and Freedom. University of Chicago Press: Chicago. Foucault M (2008) The Birth of Biopolitics. Palgrave Macmillan: New York.

Gangle R (2010) Divinatory chances. SubStance 39 (1): 76-86.

Gangle R (2015) Diagrammatic Immanence: Category Theory and Philosophy. Edinburgh University Press: Edinburgh.

Glucklich A (1997) The End of Magic. Oxford University Press: Oxford.

gotquestions.org. (n.d.) What is bibliomancy? Available from: http://www.got questions.org/bibliomancy.html, accessed 29 October 2015.

Graeber D and Piketty T (2014) "Soak the Rich", The Baffler, no. 25. Available from: http://thebaffler.com/odds-and-ends/soak-the-rich, accessed 30 October 2015.

Hacking I a n (1990) The Taming of Chance. Cambridge University Press: Cambridge.

Hartshorne C and Weiss P (eds) (1934) The Collected Papers of Charles Sanders Peirce, Vol. 5. Harvard University Press: Cambridge, MA.

Harvey D (2007) A Brief History of Neoliberalism. Oxford University Press: Oxford.

Hayek F (1944) The Road to Serfdom. University of Chicago Press: Chicago.

Hayek F (1973) Law, Legislation, and Liberty, vol. 1 University of Chicago Press: Chicago.

Heimlich E (2010) Darwin's fortune, Jonah's shipmates and the persistence of chance In: Curry P (ed) Divination: Perspectives for a New Millennium. Ashgate Publishing Limited: Farnham, UK.

Horkheimer M and Adorno T (2007) Dialectic of Enlightenment: Philosophical Fragments. Stanford University Press: Stanford.

Jung C (1967) The spirit mercurius In: Alchemical Studies. Collected Works of C.G. Jung Vol. 13, trans. R.F.C. Hull Routledge, Keegan, and Paul: London.

Jung C (2010) Synchronicity: An Acausal Connecting Principle. Princeton University Press: Princeton.

Klein N (2008) The Shock Doctrine: The Rise of Disaster Capitalism. Picador: New York.

Knight F (2009) Risk, Uncertainty, and Profit. Signalman Publishing: Kissimee, FL.
Kotsko A (2015) The arrested development of the "world come of age". 11 October An und für sich: An Anomalous Humanities Blog. Blog. Available from http:// www.itself.wordpress.com, accessed 30 October 2015.

Latour B (1993) We Have Never Been Modern. Cambridge University Press: Cambridge.

Latour B (2010) On the Modern Cult of the Factish Gods. Duke University Press: Durham, NC.

Lear J (2003) Something for Nothing: Luck in America. Viking Books: New York

Marinova P (2015) These execs say psychics are helping them make a fortune. 21 September. Fortune. Available from: http://fortune.com/2015/09/21/psychic business-advice/. accessed 29 October 2015.

Mirowski P (2002) Machine Dreams: Economics Becomes a Cyborg Science. Cambridge University Press: New York.

Mirowski P (2013) Never Let a Serious Crisis Go to Waste: How Neoliberalism Survived the Financial Meltdown. Verso: London.

Mirowski P and Piehwe D (eds) (2015) The Road From Mont Pèlerin: The Making of the Neoliberal Thought Collective. Harvard University Press: Cambridge, MA

Nagarestani R (2014) More mind and philosophy. 8 November. Deracinating Effect: Close Encounters of the Fourth Kind with Reason: Blog. Available from: http://blog.urbanomic.com/cyclon/, accessed 29 October 2015.

Nietzsche F (2001) The Gay Science. Cambridge University Press: Cambridge, UK Peck J (2010) Constructions of Neoliberal Reason. Oxford University Press: Oxford. Perkins J (2005) Confessions of an Economic Hit Man. Plume: New York.

Petikäinen J (2010) Central Asian and Northern European Shamanism In: Curry P (ed) Divination: Perspectives for a New Millennium. Ashgate Publishing Limited: Farnham, UK.

Read J (2009) A genealogy of homo-economicus: Neoliberalism and the production of subjectivity. Foucault Studies (6): 25-36.

Samuel L (2011) Supernatural America: A Cultural History. Praeger: Santa Barbara, CA.

Schmitt C (2006) Political Theology: Four Chapters on the Concept of Sovereignty. University of Chicago Press: Chicago.

Shaviro S (2015) No Speed Limit: Three Essays on Accelerationism. University of Minnesota Press: Minneapolis.

Taleb N (2010) Black Swan: The Impact of the Highly Improbable. Random House: New York.

Taussig M (2003) Viscerality, faith, and skepticism: Another theory of magic In: Meyer B and Pels P (eds) Magic and Modernity: Interfaces of Revelation and Concealment. Stanford University Press: Stanford, pp 272-306.

Tedlock B (2010) Theorizing divinatory acts: The integrative discourse of dream oracles In: Curry P (ed) Divination: Perspectives for a New Millennium. Ashgate Publishing Limited: Farnham, UK.

Viveiros de Castro E (2004) Exchanging perspectives: The transformation of objects into subjects in Amerindian cosmologies. Common Knowledge; 10 (3): 463-484.

Weber M (2009) The Protestant Ethic and the Spirit of Capitalism. W.W. Norton \& Co.: New York.

Zalamea F (2012) Synthetic Philosophy of Contemporary Mathematics. Urbanomic: Falmouth, UK.

\section{Data Availability}

Data sharing not applicable to this paper as no datasets were generated or analysed during the current study.

\section{Additional Information}

Competing interests: The authors declare no competing financial interests.

Reprints and permission information is available at http://www.palgrave-journals.com/ pal/authors/rights_and_permissions.html

How to cite this article: Ramey J (2015) Neoliberalism as a political theology of chance: The politics of divination. Palgrave Communications. 1:15017 doi: 10.1057/ palcomms.2015.39.

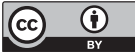

This work is licensed under a Creative Commons Attribution 3.0 International License. The images or other third party material in this article are included in the article's Creative Commons license, unless indicated otherwise in the credit line; if the material is not included under the Creative Commons license, users will need to obtain permission from the license holder to reproduce the material. To view a copy of this license, visit http://creativecommons.org/licenses/by/3.0/ 